\title{
DOCUMENTATION AND STRUCTURAL APPRAISAL OF THE MEDIEVAL MANOR OF POTAMIA, CYPRUS: AN INTERDISCIPLINARY APPROACH
}

\section{ROGIROS ILLAMPAS ${ }^{1 *}$, DIOMEDES MYRIANTHEFS ${ }^{2}$, DORIA NICOLAOU ${ }^{3}$, VASILIKI LYSANDROU ${ }^{3}$, MARIA PHILOKYPROU ${ }^{2}$, GEORGE PAPASAVVAS ${ }^{3}$ AND IOANNIS IOANNOU ${ }^{1}$}

\author{
Departments of ${ }^{1}$ Civil and Environmental Engineering, ${ }^{2}$ Architecture and ${ }^{3}$ History and Archaeology \\ University of Cyprus \\ University of Cyprus, 75 Kallipoleos Street, P.O. Box 20537, 1678 Nicosia, Cyprus \\ e-mail: rilamp01; myrianthefs.diomedes; nicolaou.doria; lysandrou.vasiliki; mphiloky; georgep; \\ ioannis @ucy.ac.cy, \\ www.ucy.ac.cy
}

Keywords: Historical Structure, Masonry, Monitoring, Non-Destructive Inspection

\begin{abstract}
This paper aims to present, via a case study, an interdisciplinary approach towards the comprehensive analysis of historic constructions. The case study monument examined is the Medieval Manor of Potamia in Cyprus. The work hereby presented was based on a collaboration between scientists from the fields of archeology, architecture, materials science/ conservation and structural engineering. A thorough review of historical sources was initially carried out in order to obtain data concerning the history and construction development of the Manor. Extensive field work was undertaken to study the architectural typology and construction detailing of the structures and to explicitly map the various agents of pathology. For the characterization of the historic fabric, masonry materials were sampled and studied at the laboratory. The accumulated data facilitated the development of a Finite Element (FE) model, which was used to numerically assess the structure's seismic response.
\end{abstract}

\section{INTRODUCTION}

The paper reflects on practical applications of interdisciplinary collaboration in the context of historic building preservation. An operational procedure for the analysis of such heritage constructions is hereby presented through the case study of the Medieval Manor of Potamia in Cyprus. The Manor is a composite building complex that incorporates stone and adobe masonry structures dating from the $14^{\text {th }}$ to the $20^{\text {th }}$ century. Although the west part of the building complex has rather recently been restored, the east part remains in a ruinous condition. Detailed investigations for the documentation and structural appraisal of the Manor's east part were undertaken in the framework of this study. In this context, based on archaeological and literature sources, the major events which took place during the lifetime of the monument were examined, in order to identify the evolution of the structure. An 
architectural survey was also conducted for the geometrical description of the monument and the documentation of construction detailing. A condition assessment was performed to detect any inherent deficiencies or degradation phenomena that affect the structural behavior. Furthermore, investigations necessary to achieve an adequate knowledge level regarding the mechanical properties of the historic fabric were carried out. These were based on the laboratory testing of materials sampled from the monument. The collected data facilitated the development of a numerical model, which was used for examining the seismic vulnerability of the structure. The main outputs derived at each step of the study are hereby discussed, illustrating aspects connected with the correct understanding, interpretation and analysis of heritage constructions.

\section{HISTORIC ANALYSIS OF THE MONUMENT}

Historic study, carried out in the framework of this project, revealed important information regarding the erection and later development of the Manor. According to some sources [1], the construction of the Manor is dated between 1369-82 AD, during the reign of King Peter II, while according to other researchers [2] [3] it was built by King James I (1382-98 AD). Narratives from the visit of Marquis Niccolò III d' Este to Cyprus (1412 AD) describe the Manor as a place with beautiful view, gardens, fountains and stables [4]. The Manor was used as a royal lodging place until 1426 [3], when it was burned down by Mameluke invaders [1].

In 1521-70 AD, the site possibly came to the possession of the Venetian noble Zegno Singlitico, who repaired the Nanor, along with the area's irrigation system and mills [5].
After the Ottoman conquest of the island in $1570 \mathrm{AD}$, the Mlanor became a private land
holding (i.e. a Chiflik) of Ibrahim Menteschologhlou [5]. It is reported that in the $17^{\text {th }}$ and
centuries, building material removed from the Manor Was used for the construction of hamam
baths at the site, and of the Panagia Faneromeni church in Nicosia [6].
By the late $19^{\text {th }}$ centtury, the Manor complex had bect divided into separate family-ortned properties. All title deeds were eventually sold to the Demetriou family in the early $20^{\text {th }}$

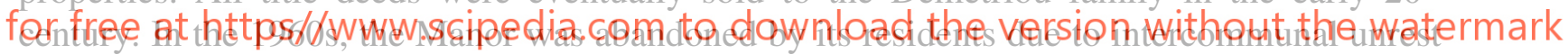
and was used as a stable and a warehouse by the people of the nearby village. In 1974, the site was converted into a military camp by the Cyprus National Guard. In 1988, the Demetriou family donated part of the Manor to the Department of Antiquities of Cyprus and a study [7] for the documentation of the monument was carried out. Sections of the structures collapsed during an earthquake in 1996. Archeological surveys and excavations by the Department of Antiquities, the University of Cyprus and the University of Provence (Aix-Marseille I) were conducted in 2000-04 [8] and 2009-10 [9], and in 2005 further architectural documentation studies were commissioned. In 2019, a rehabilitation scheme that was subsidized by the Department of Antiquities of Cyprus addressed the restoration of the west part of the Manor.

\section{ARCHITECTURE AND CONSTRUCTION TYPOLOGY}

Following the historic study of the monument, field investigations and topographic surveys were conducted to identify the various elements composing the structure and to study their construction detailing. The load-bearing system consists of stone and adobe masonry walls, upon which timber floors and roofs rest. The thickness of the masonry sections varies from 45 to $80 \mathrm{~cm}$, depending on the type and age of the construction. Three main building phases 
(Figure 1) have been identified:

- Phase I (1380-1426): Medieval structures built before the destruction of the Manor by the Mamelukes. These include masonry sections composed of coursed ashlar stones.

- Phase II (1426-1570): Elements added/reconstructed during the Frankish and Venetian periods. These are stone masonry sections incorporating reused ashlar blocks.

- Phase III (1571-20 ${ }^{\text {th }}$ century): Additions/modifications made during the Ottoman period and up to the $20^{\text {th }}$ century. Such structures are generally constructed of adobe masonry.

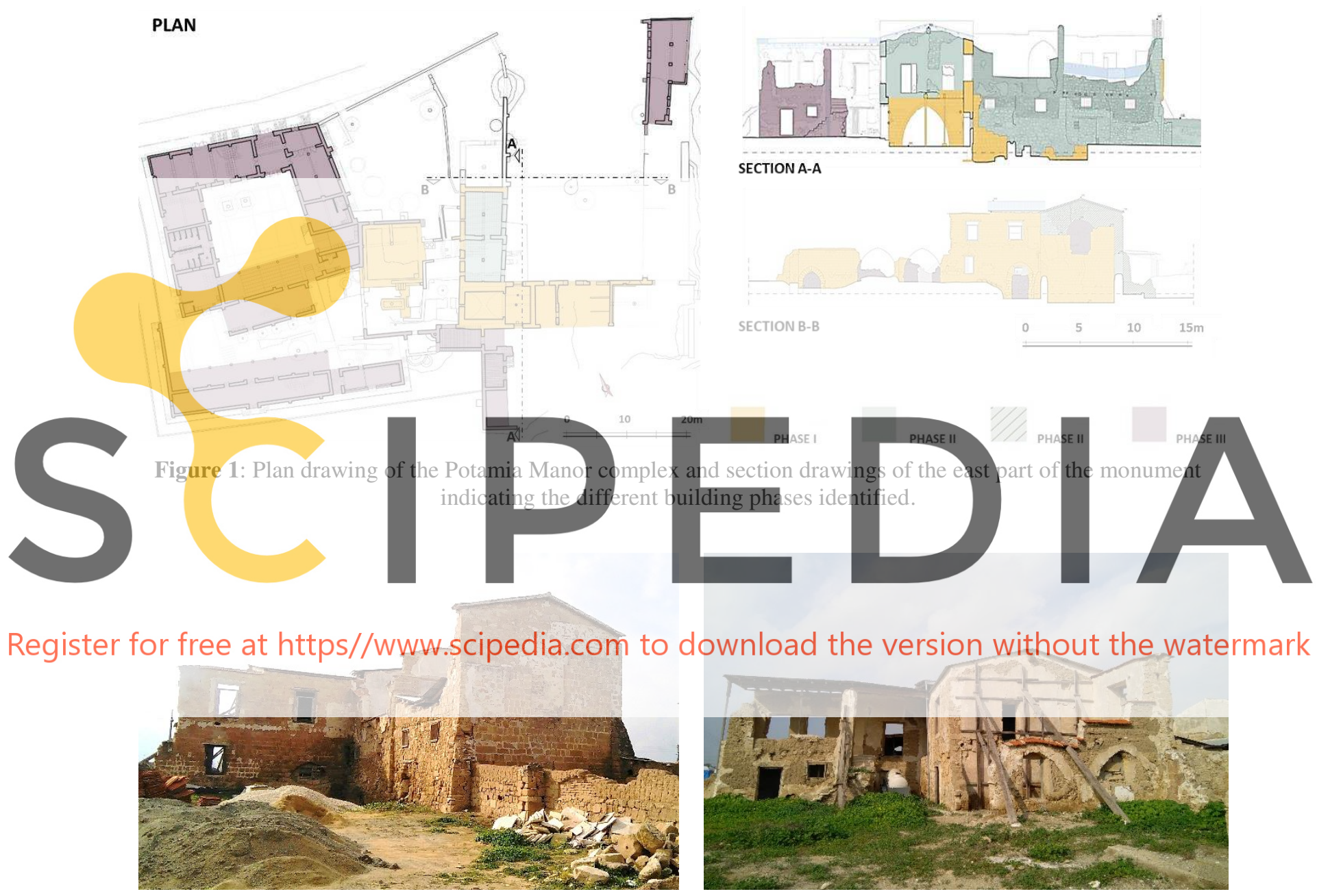

Figure 2: Photographs of the east part of the Potamia Manor showing stone masonry structures facing towards the north (left) and adobe constructions attached to stone structures at the south (right).

The Manor building complex occupies a plan area $>5500 \mathrm{~m}^{2}$. The east and west parts of the complex are separated by a courtyard that includes the remnants of a large water tank and a well. The east part mainly consists of one-storey high stone masonry constructions dated to the $14^{\text {th }}-16^{\text {th }}$ century, with several later modifications/additions of stone and adobes (Figure 2). Building spaces are rectangular in layout. Pointed arches that originally supported the floor structures are encountered at the interior of some rooms. A number of walls feature arched openings, some of which have been blocked. At the ground floor of this building part, a 
vaulted room of unknown use exists. This is considered to be the only medieval structure surviving to its original height. Towards the south, adobe constructions were attached to the pre-existing stone structures. Many sections of the east part, including most of the roof and floor structures, and large segments of the walls at the upper floor, have collapsed.

The west part of the building complex was added during the Ottoman era. It comprises of a series of rooms, a longitudinal semi-open space (iliakos) and a portico (semi-open passthrough entrance) arranged around a central courtyard. A longitudinal building (with an iliakos on the north), which presumably served as a stable, is placed along the south boundary. All structures of the west part have nowadays been restored.

\section{INVESTIGATION OF THE PATHOLOGY OF THE MONUMENT}

A meticulous diagnostic survey was performed to examine the existing building pathology. The work included site inspections and detailed photographic documentation. Field measurements of (i) the moisture content of masonry walls, (ii) the crack mouth opening and (iii) the depth to which surface erosion has affected the building materials were carried out. These were conducted using dual electrode pin moisture meters, metric scales and pit gauges. The accumulated data were utilized for the preparation of drawings mapping the recorded pathologies.

It was noted that the main agents of pathology are associated with the action of water, and especially salt crystallization. The absence of waterproofing courses at the foundation level from the ground indica with the sharp front theor of roofing protection exposed to the climatic the top of the walls
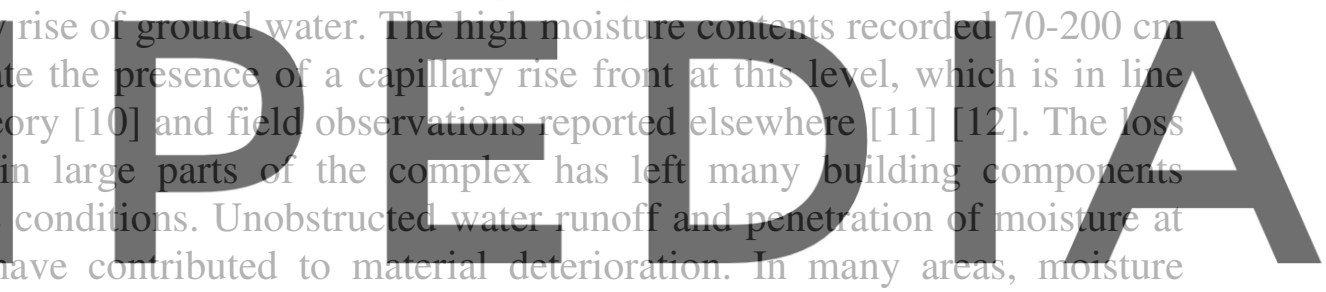

infiltration, combined with thermal distress, have caused the detachment of render and plaster

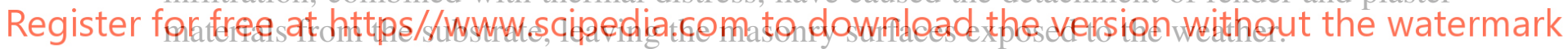

Adobe materials exhibit severe weathering due to the susceptibly of unfired earth to moisture-driven disintegration [13] [14]. Surface crosion characterized by lose of cohesion of the soil matrix was recorded on most earthen walls. Deterioration of adobes induced by rising damp has led to the formation of continuous horizontal fissures along the boundary between the walls' stone base and the adobe masonry, where the evaporation front is located (Figure 3a). Moisture-driven damage on stone walls is more noticeable at the sections affected by rising damp. At these areas, the jointing mortar has weathered away to a depth of $5-15 \mathrm{~cm}$ from the face of the masonry, while many stone blocks have suffered spalling and have become rather friable (Figure 3b). Biodegradation of masonry materials by lichens/mosses, as well as mechanical damage caused by vegetation growing next to or within the mass of the walls occur. Many of the remaining timber members were found to be in rather poor state, showing signs of insect infestation and/or fungal decay.

In terms of structural damage, the major issues identified are partial collapse of masonry sections, cracking (Figure 3c), loss of interaction among interconnected members and deformation of wall elements (i.e. bulging, loss of verticality). Measured crack widths were in many cases $\geq 10 \mathrm{~mm}$, while the presence of through-cracks indicating separation among 
orthogonal walls was recorded. Structural damage has been caused by the joint action of several factors, including seismic loading, climatic conditions, defects associated with original construction methods/materials, incompatible/ineffective interventions and application of excessive loads on the structure due to changes in building use. The lack of adequate connection between parts of the monument constructed at different building phases and the inherent absence of stiff floor and roof diaphragms have also affected the structural response.

(a)

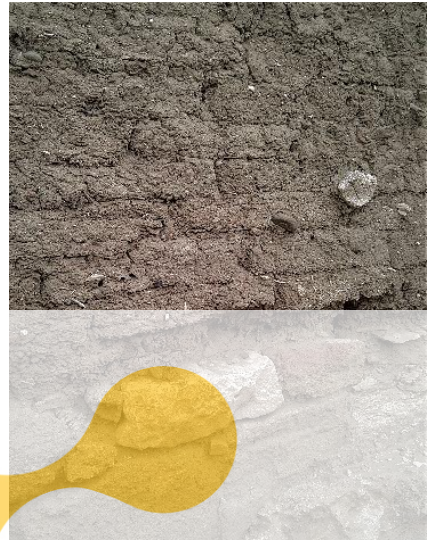

(b)

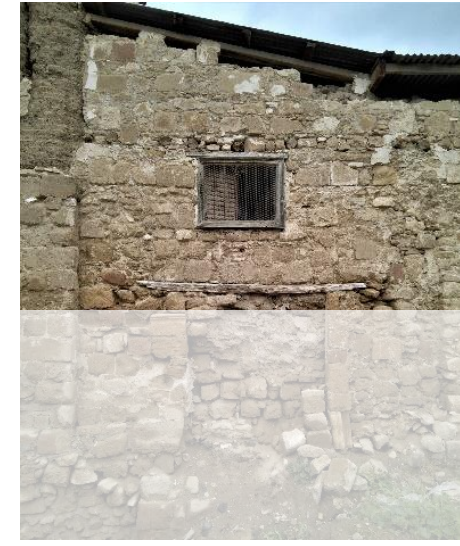

(c)

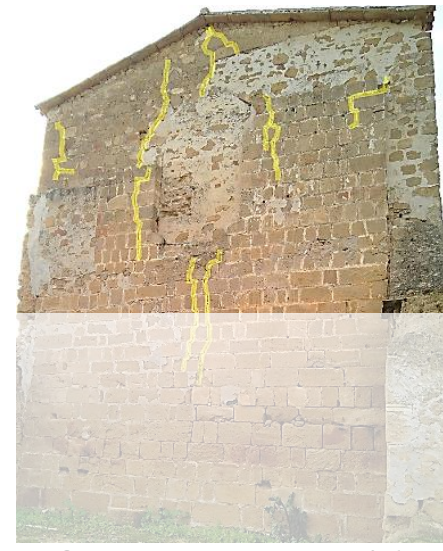

Figure 3: (a) Undercutting and surface erosion of adobe masonry. (b) Deterioration of stone masonry materials due to rising dump. (c) Marking of crack locations on the stone masonry wall of the north elevation.
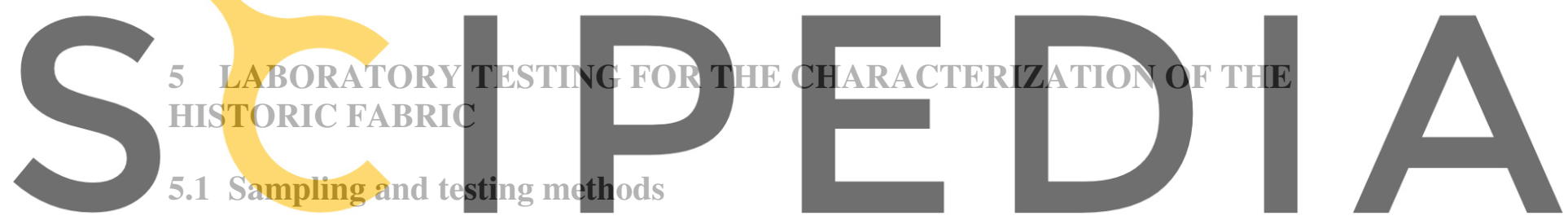

In order to assess the characteristics of the historic materials, building stones, adobe bricks,

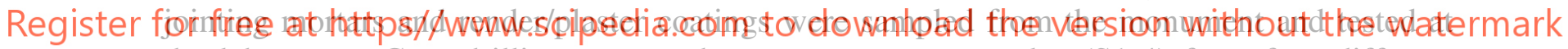
the laboratory. Core drilling was used to extract stone samples (S1-4) from four different masonry blocks. Portions of adobe bricks were cut from exposed parts of the walls. Fragments of mortar (M1-3) were sampled from the joints of the stonework. Mortar samples were also obtained from earth-based coatings covering the surfaces of the adobe masonry walls.

For the implementation of tests on building stones, cylindrical specimens with nominal dimensions diameter $=$ height $=55 \mathrm{~mm}$ were formed from the core samples via wet diamond sawing. Prior to testing, all stone specimens were oven-dried to constant mass at $70{ }^{\circ} \mathrm{C}$. The apparent density and open porosity of the stone materials were measured through vacuum assisted saturation and submerged weighting, as per EN 1936 [15]. For the determination of the capillary absorption coefficient, water absorption tests were carried out in accordance with EN 1925 [16]. The compressive strength was assessed via uniaxial loading tests based on EN 1926 [17]. Loading was imposed under a displacement-controlled rate of $0.2 \mathrm{~mm} / \mathrm{min}$ using a $300 \mathrm{kN}$ capacity mechanical press. In all types of tests, three specimens from each stone block sampled were examined. The mineralogy of the stones was investigated through qualitative and semi-quantitative XRD analyses on powder samples. Locked-coupled continuous scans at $2 \theta$ angles from $2^{\circ}$ to $100^{\circ}$ were performed. XRD analyses were carried out on two of the four stone samples hereby examined. 
Cubic specimens with a nominal side length of $50 \mathrm{~mm}$ were dry cut from the adobe brick portions sampled and were subjected to uniaxial compression tests. The bearing surfaces of the specimens were capped with gypsum mortar in order to achieve a uniform distribution of stresses during the tests. Loading was again applied under displacement control, at a rate of 1 $\mathrm{mm} / \mathrm{min}$, using a $10 \mathrm{kN}$ capacity load cell. Tests were performed on three adobe specimens.

In order to obtain information regarding the mix components of the jointing mortars incorporated in stone walls, fractionation of the sampled materials was performed. Three samples originating from different parts of the monument were examined. The mortars were initially crushed to roughly segregate the aggregates from the binder. The processed material was then immersed in acetone. Repeated cycles of sonication and sieving through a $0.063 \mathrm{~mm}$ sieve were conducted to separate the binder and aggregate fractions. The dry weights of the fragments passing through $\left(m_{b}\right)$ and retained on $\left(m_{a}\right)$ the sieve were measured. Based on the hypothesis that the material with particle size $<0.063 \mathrm{~mm}$ consists mostly of the binder, the binder:aggregate (b:a) ratio of the sample was computed as $m_{b}: m_{a}$. Semi-quantitative XRD analyses were conducted on the fractionated binder and aggregate constituents of the samples. In all cases locked-coupled continuous scans at $2 \theta$ angles from $2^{\circ}$ to $70^{\circ}$ were undertaken.

The characterization of the earth coatings involved evaluation of the samples' contents in fines (silt and clay, $d<0.063 \mathrm{~mm})$, sand $(0.063 \mathrm{~mm} \leq d<2.36 \mathrm{~mm})$ and fibers. Two samples were examined. Separation of the fibers from the soil matrix was achieved by submerging the samples into water and allowing the soil to settle and the fibers to float on the surface. The segregated fibers were dried and weighted. The soil portions were also dried and sieved through $5,2.36,1.18,0.600,0.250,0.150 \mathrm{~mm}$ and $0.063 \mathrm{~mm}$

\subsection{Experimental results and cliscussiom \\ The experimental results obtained from}

summarized in Table 1

The stor

porosity. The apparent density and open porosity of samples S2-4 were found to be in the

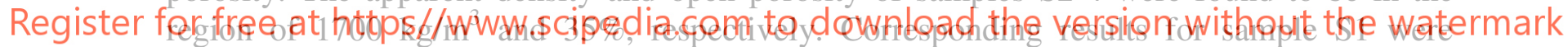
somehow different, the average apparent density being $1940 \mathrm{~kg} / \mathrm{m}^{3}$ and the percentage of open pores approaching 26\%. The porous structure of the materials explains the high rates of water absorption recorded. Capillary absorption coefficients for samples S2-4 lied between 1000 and $1400 \mathrm{~g} / \mathrm{m}^{2} \mathrm{~s}^{1 / 2}$, while specimens originating from sample $\mathrm{S} 1$ produced variable results in the range of $40-325 \mathrm{~g} / \mathrm{m}^{2} \mathrm{~s}^{1 / 2}$. A load-bearing capacity near $4.5 \mathrm{MPa}$ was assessed for samples S2 and S3. Sample S2 also exhibited low compressive strength $(<2.5 \mathrm{MPa})$. As expected, the load-bearing capacity of the relatively less porous $\mathrm{S} 1$ sample was superior to those of the other stones; $15 \mathrm{MPa}$. XRD analysis of samples S1 and S4 verified that the materials under study are sedimentary stones rich in calcite (> 70\%). Sample S4 is composed of $72 \%$ calcite, containing considerable amounts (9-14\%) of plagioclases (i.e. albite and anorthite) and quartz. The monocrystalline mineral structure of stone S1 ( 100\% calcite) may explain to some extent the lower porosity and higher strength of this sample.

The test results for stone masonry jointing mortars are reported in Table 2. The high percentage content $(\geq 80 \%)$ of gypsum identified in the binder fraction of samples M1 and M3 points towards the use of gypsum-based mortars. The aggregate fraction of these two samples was also found to be rich in gypsum (> 80\%), indicating that gypsiferous aggregates 
may have been used. The presence of gypsum-based jointing mortars in local historic constructions dating well before the construction of the Manor (i.e. 500 BC) is reported by Wright [18]. Sample M2 has been identified as a lime mortar, since its binder fraction is almost entirely composed of calcite. Considering that calcite, quartz and plagioclases are the predominant minerals in the aggregate fraction of this mortar, it can be presumed that local calcareous sand was used in its mix design. The $\sim 1: 3 \mathrm{~b}$ :a ratio assessed for M9 is totally in line with traditional construction practices in Cyprus.

The two earth-based coating samples examined were found to be rich in fines. The ratios between the particles $<0.063 \mathrm{~mm}$ and those belonging to the sand fraction were 1:0.03 and 1:0.10, respectively. The estimated fiber contents expressed as a percentage of the soil weight were $21 \%$ and $7 \%$. These well exceed the amount of fibers traditionally used in Cyprus for the fabrication of adobe bricks [19]. Since earth renders were intended to be exposed to climatic conditions, it is reasonable to expect that high fibrous content had to be used in order to account for shrinkage effects induced by frequent wetting and drying.

Table 1: Average properties (coefficient of variation) and mineralogical composition of stone samples.

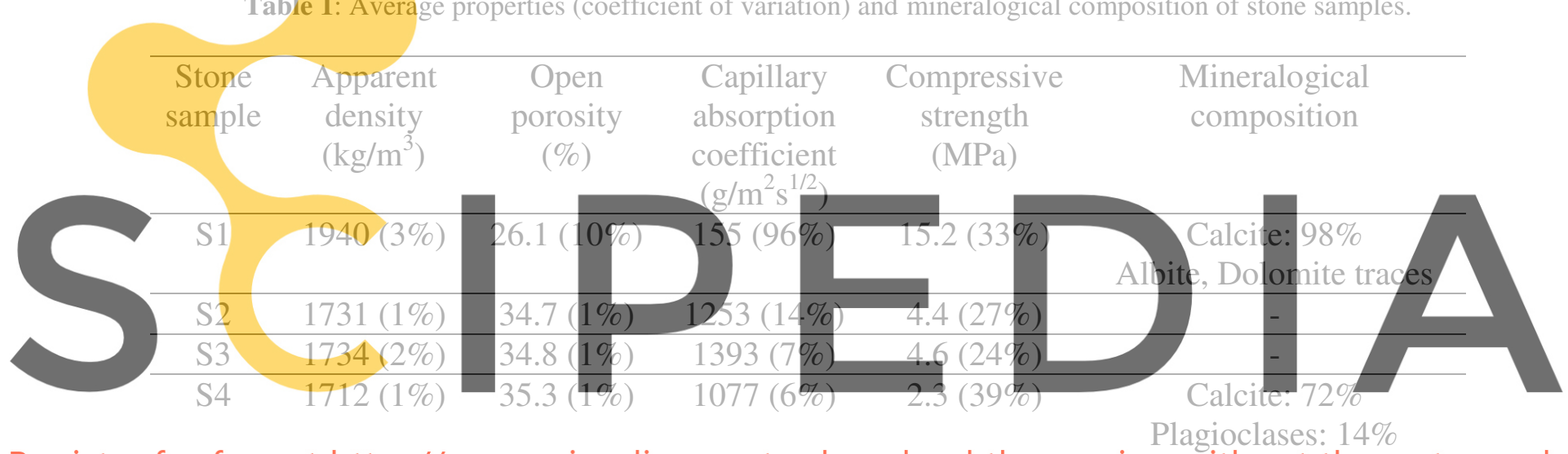
Register for free at https//www.scipedia.com to download the version withatt totae watermark

Dolomite, Chlorite traces

Table 2: Binder:Aggergate ratios and mineralogy of the constituent fractions of jointing mortars.

\begin{tabular}{cccc}
\hline Mortar & Binder: Aggregate & \multicolumn{2}{c}{ Mineralogical composition } \\
\cline { 2 - 3 } sample & ratio (w/w) & Binder fraction & Aggregate fraction \\
\hline M1 & $1: 0.3$ & Gypsum: $90 \%$ & Gypsum: $94 \%$ \\
& & Calcite: $4 \%$ & Calcite: $4 \%$ \\
& & Calcite: $90 \%$ & Plagioclases traces \\
\hline M2 & $1: 2.8$ & Calcite: $60 \%$ \\
& & Quartz, Plagioclases, & Quartz: $10 \%$ \\
& & Gypsum, Chlorite traces & Plagioclases: $27 \%$ \\
& & Gypsum: $80 \%$ & Gypsum, Chlorite traces \\
\hline M3 & $1: 0.5$ & Calcite: $17 \%$ & Gypsum: $83 \%$ \\
& & Calcite: $15 \%$ \\
& & & Plagioclases traces
\end{tabular}




\section{APPRAISAL OF SEISMIC RESPONSE}

\subsection{FE modelling}

In order to assess the seismic vulnerability of the monument, a FE model was developed in Abaqus/CAE (Figure 4). The stone-mortar and adobe-mortar masonry composites were treated as homogenous continua and were modelled using an isotropic elasticity constitutive law. Plane stress failure measures were specified for identifying damage. The FE mesh consisted 3-noded shell elements with five integration points through the thickness and an average side length of $0.4 \mathrm{~m}$. Pinned supports were defined along the walls' base.

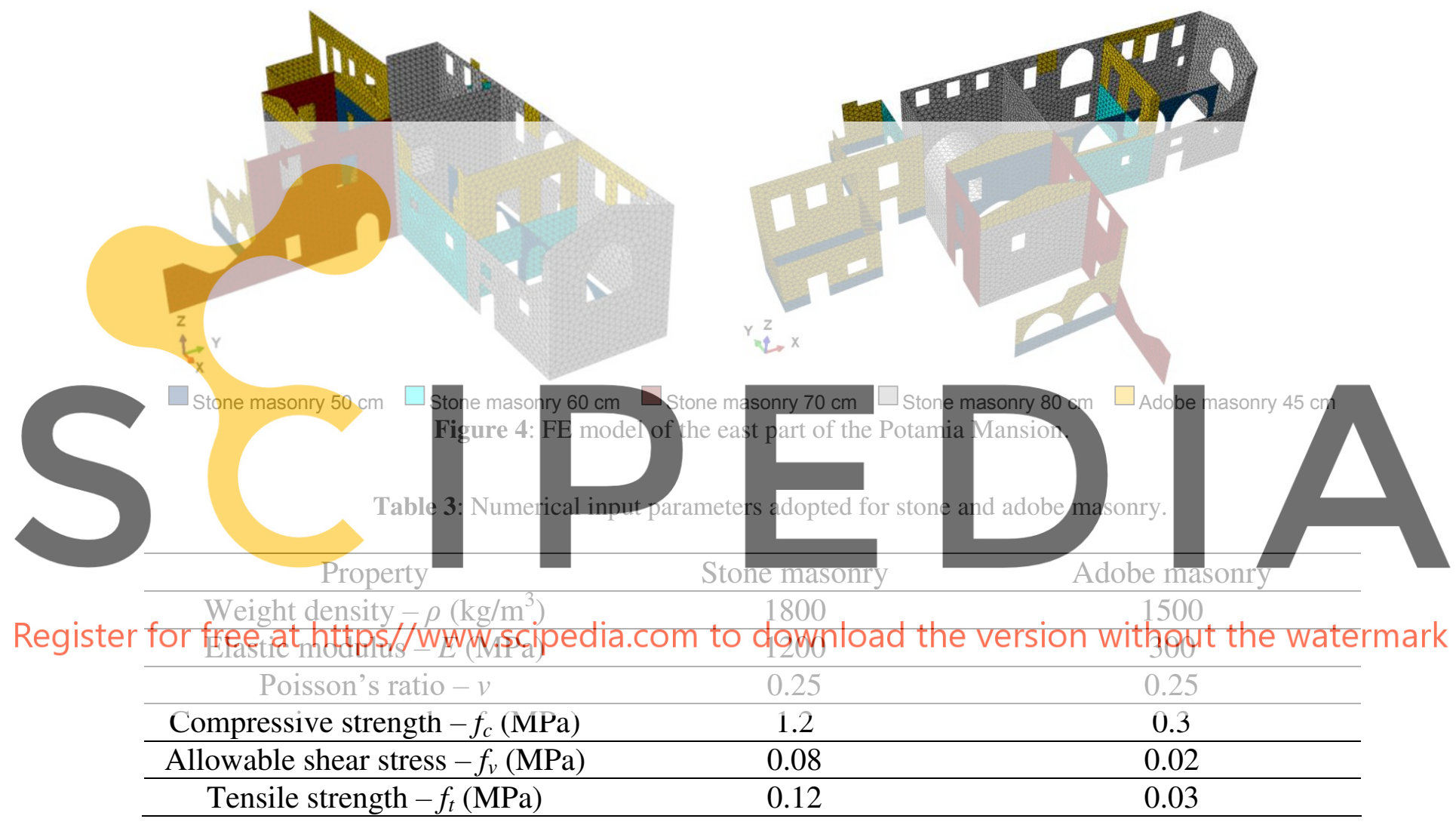

Numerical input parameters (Table 3) were based on the experimental data derived in this study. The weight density of stone masonry was defined as $1800 \mathrm{~kg} / \mathrm{m}^{3}$, in accordance with the properties of the stone materials. The respective value assumed for adobe masonry is 1500 $\mathrm{kg} / \mathrm{m}^{3}$. Compressive strength $\left(f_{c}\right)$ was estimated as $f_{c}=K f_{b}{ }^{0.7} f_{m}{ }^{0.3}$ [20]. In this relation $f_{b}$ and $f_{m}$ are the compressive strengths of the masonry units and jointing mortar and $K$ is a parameter accounting for the construction pattern. With reference to the results of loading tests, $f_{b, s}=4$ $\mathrm{MPa}$ and $f_{b, a}=0.6 \mathrm{MPa}$ were taken for the strengths of the stone blocks and adobe bricks, respectively. A value of $f_{m, s}=1 \mathrm{MPa}$ was assumed for the gypsum and lime mortars incorporated in the stonework [21]. For earth mortar $f_{m, a}=f_{b, a}=0.6 \mathrm{MPa}$ was adopted, as the composition of this material is typically the same as that of the adobe bricks. A value of $K=$ 0.45 [20] was taken for stone masonry. In the absence of code prescribed clauses for adobe 
masonry, $K=0.55$ was adopted. The aforementioned material properties yielded $f_{c, s}=1.2$ $\mathrm{MPa}$ for stone masonry and $f_{c, a}=0.3 \mathrm{MPa}$ for adobe masonry. Maximum allowable stress under shear $\left(f_{v}\right)$ was estimated as $f_{v}=0.065 f_{c}$ [20]. Tensile cracking strength $\left(f_{t}\right)$ was empirically taken as $f_{t}=0.1 f_{c}$. Elastic moduli $(E)$ were approximated by $E=1000 f_{c}$ [20]. A value of $v=0.25$ was assumed for the Poisson's ratio of both masonry typologies.

To assess whether imposed actions result to load-carrying demands which exceed the capacity of masonry sections, a stress-based failure criterion [22] was implemented. According to this criterion, the failure surface in the stress space $\left\{\sigma_{x}, \sigma_{y}, \tau\right\}$ is given by:

$$
f\left(\sigma_{x}, \sigma_{y}, \tau\right)=F_{1} \sigma_{x}+F_{2} \sigma_{y}+F_{11} \sigma_{x}^{2}+F_{22} \sigma_{y}^{2}+F_{66} \tau^{2}+F_{12} \sigma_{x} \sigma_{y}
$$

The parameters of this polynomial are (strength) tensors estimated as:

$F_{1}=1 / f_{c, x}+1 / f_{t, x} ; F_{2}=1 / f_{c, y}+1 / f_{t, y} ; F_{11}=-1 / f_{c, x} f_{t, x} ; F_{22}=-1 / f_{c, y} f_{t, y} ; F_{66}=1 / f_{v}^{2}$ and $F_{12}=k\left(F_{11} F_{22}\right)^{1 / 2}$ for $k=-0.3$. Although the failure surface can account for orthotropic strength measures, in this study it was assumed that masonry has the same compressive and tensile strengths along the two principal directions $\left(f_{c, x}=f_{c, y}=f_{c} ; f_{t, x}=f_{t, y}=f_{t}\right)$. The assessment criterion provides indications of material failure based on the post-processing of numerically computed elastic stresses and does not introduce material degradation properties into the analysis process. The outcome is expressed by means of a failure index $(R)$ which indicates whether damage due to exceedance of the permissible stress state is predicted to occur $(R \geq 1)$ or not $(0 \leq R<1)$.

\subsection{Numerical analysis and results}

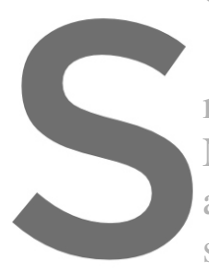

Analysis of the monumen method and adopting th National Annex to acceleration for the Pot silt, clay and gravel; the ground may be classifi horizontal elastic response spectrum defined by periods $T_{B}=0.15 \mathrm{~s}, T_{C}=0.50 \mathrm{~s}, T_{D}=2.0 \mathrm{~s}$ and

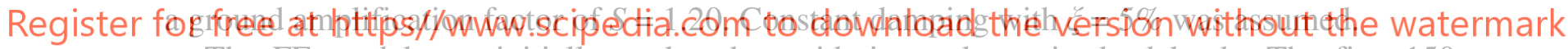

The FE model was initially analyzed considering only static dead loads. The first 150 eigenvectors of the system were then extracted using the Lanczos eigensolver. Complete quadratic combination of modal maxima was subsequently applied for computing unidirectional response along the $X$ and $Y$ axes with respect to the code prescribed spectrum. The results from the static and multimodal superimposition steps were superimposed in order to estimate the response of the structure for various load cases deduced by the combinations of quasi-permanent $(G)$ and seismic $\left(E_{X}\right.$ and $E_{Y}$ ) actions $G \pm E_{X} \pm 0.3 E_{Y}$ and $G \pm 0.3 E_{X} \pm E_{Y}$.

Modal analysis yielded a multitude of modes having low mass participation. Inevitably, a structurally meaningful predominant mode of vibration could not be defined. The first 150 eigenvectors engaged $80 \%$ and $77 \%$ of the total structural mass in the $X$ and $Y$ directions, respectively. The predicted mode shapes indicate that dynamic behavior is governed by outof-plane motion of individual wall elements. This was pretty much expected due to the absence of diaphragms at the floor and roof levels and the partial collapse of masonry sections, which resulted to lack of adequate restrain along the edges of many surviving walls.

Figure 5 presents contour diagrams of damage variable $R$ over deformed FE meshes for load combinations corresponding to different directions of the principal seismic component. Good correlation between numerically predicted damage and recorded cracking is observed at 
many of the stone walls (e.g. compare the crack pattern of the north elevation wall shown in Figure $3 \mathrm{c}$ with the corresponding areas exhibiting $R>5$ in Figure 5). This provides a useful indication regarding the validity of the computational model. Analyses show widespread damage due to exceedance of allowable stress state. For all load combinations examined > $60 \%$ of the total surface area of the shell elements develop stresses outside the failure envelopes defined. According to Asteris [24], this can be interpreted as the structure reaching the near collapse limit state.

The computed deformation distribution indicates that the walls which sustain out-of-plane seismic loading are susceptible to overturning. This failure mode appears to be critical for the walls and parapets of the upper floor and for certain free-standing wall sections at the ground floor level. It is evident that adobe constructions are the most vulnerable parts of the monument. The low modulus of earth masonry results to the development of high deformations at these sections. In addition, the poor mechanical properties of adobe are not adequate for resisting the significant demands imposed by seismic action, particularly at wall sections which are not effectively restrained against lateral motion. Overall, spatial discontinuity of the load-bearing system due to partial collapse of sections and variation of the stiffness and mass distribution within the walls negatively affect global seismic response.

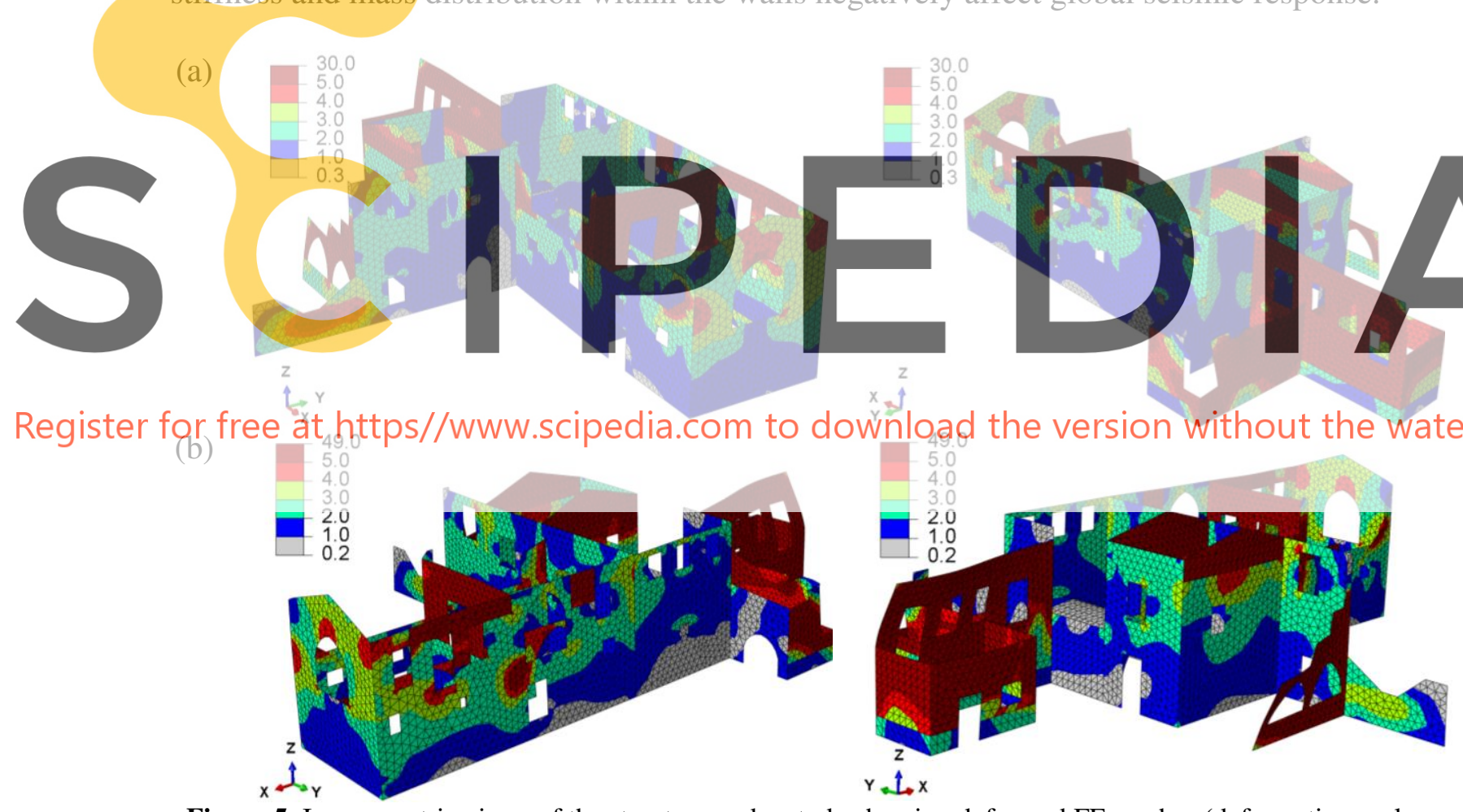

Figure 5: Isoparametric views of the structure under study showing deformed FE meshes (deformation scale $\mathrm{x}$ 20 ) with contour diagrams of damage variable $R$ for load combinations (a) $G+E_{X}+0.3 E_{Y}$ and (b) $G-0.3 E_{X}-E_{Y}$.

\section{CONCLUSIONS}

An integrated methodology linking historic, architectural and structural analysis was adopted for the documentation and appraisal of the Medieval Manor of Potamia, Cyprus. The research included review of existing sources, field investigations, sampling and testing 
campaigns and numerical assessment studies. The monument examined was found to consist of several building phases dating from the $14^{\text {th }}$ to the $20^{\text {th }}$ century. Its load-bearing system is composed of stone and adobe masonry walls. Significant structural damage was detected, including partial collapses, separation among orthogonal walls and extensive cracking. Furthermore, it was noted that the building materials suffer from moisture-driven decay due to inadequate protection against ground and rainwater infiltration. Tests for the characterization of the building fabric revealed that a porous sedimentary stone of relatively low compressive strength $(<10 \mathrm{MPa})$ was used for the construction of the stonework, along with lime- and gypsum-based jointing mortars. Poor mechanical properties were determined in the case of adobe materials, owing to the susceptibility of raw earth to water-mediated damage. Seismic analysis conducted using the response spectrum method showed that the monument is particularly vulnerable to earthquake action. Out-of-plane failure of poorly restrained masonry sections was found to be the critical mechanism governing seismic response. It was concluded that the structural behavior is adversely affected by inherent deficiencies, such as the lack of monolithic connections and the absence of stiff diaphragms, as well as by the pathology of the monument. Regarding the latter, degradation of mechanical properties and loss of the loadbearing system's spatial continuity due partial collapse have been identified as the factors with the most severe impact. The multifaceted approach hereby presented clearly shows that interdisciplinary collaboration is a key aspect for the comprehensive appraisal of historic constructions and hence a prerequisite for the design of appropriate intervention schemes.

Acknowledgements. The work was carried out at the University of Cyprus in the framework of the interdepartmental postgraduate program 'Conservation and Restoration of Historic Buildings and Sites'. The authors gratefully acknowledge the valuable input of postgraduate students Elina Varnava, Marios Georgiou, Malvina Yiapa, Constantinos Gavalis, Ioanna Elia, Natasa Kotsoni, Mikaella Kounnapi, Ioanna Petrou, Maria Solomou, Theodora Hadjipetrou and Stelios Hadjisoteriou.

\section{REFERENCES}

[1] Léonce Machéras, Chronique de Chypre, (french translation by E. Miller and C. Sathas), Paris: Ernest Leroux Editeur, 1882.

[2] E. de Lusignan, Description de toute l'isle de Cypre, Paris: G. Chaudière, 1580 (reprint Nicosia 2004).

[3] Archimandrite Kyprianos, Chronological history of Cyprus, Venice, 1778 (Nicosia 1902).

[4] G. Grivaud, Excerpta Cypria nova. Voyageurs occidentaux à Chypre au xvème siècle, (Sources et études de l'histoire de Chypre, XV.) Nicosia: Centre de Recherches Scientifiques, 1990.

[5] N. Lécuyer, "Marqueurs identitaires médiévaux et modernes sur le territoire de Potamia-Agios Sozomenos," in Identités croisées en un milieu méditerranéen: le cas de Chypre, S. Fourrier \& G. Grivaud (eds), Rouen, France, pp. 241-256, 2006.

[6] N. Lécuyer, "Le territoire de Potamia aux époques médiévale et moderne: acquis récents," Cahiers du Centre d'Études Chypriotes , vol. 34, pp. 11-30, 2004.

[7] S.F. Zesimou, Inventory and documentation for preservation of the royal manor of Potamia, Final Report[s.1.]: Groupement européen des campus, 1996. 
[8] N. Lécuyer and D. Michaelides, "Archaeological survey at Potamia-Ayios Sozomenos," In Archaeological Field Survey in Cyprus. Past History, Future Potentials. Proceedings of a Conference held by the Archaeological Research Unit of the University of Cyprus, 1-2 December 2000, M. Iacovou (ed.), London: British School at Athens Studies, vol. 11, pp. 139-149, 2004.

[9] Department of Antiquities, Annual Report of the Department of Antiquities for the year 2010, Nicosia: Printing Office of the Pepublic of Cyprus, 2016.

[10] C. Hall and W. Hoff, "Rising damp: capillary rise dynamics in walls," Proceedings of The Royal Society A, vol. 463, pp. 1871-1884, 2007.

[11] G. Massari and I. Massari, "Damp Buildings, Old and New," Bulletin of the Association for Preservation Technology, vol. 17, no. 1, pp. 2-30, 1985.

[12] M. Müller, Handbuch ausgewählter Klimastationen der Erde, Trier: University of Trier, Forschungsstelle Bodenerosion, 1983.

[13] R. Illampas, I. Ioannou and D. Charmpis, "Overview of the pathology, repair and strengthening of adobe structures," International Journal of Architectural Heritage, vol. 7, no. 2, pp. 165-188, 2013.

[14] I. Ioannou and R. Illampas, "Durability of earth masonry," in Long-term performance and durability of masonry and historical structures, Ghiassi B. and Lourenco P.B., Eds., Woodhead Publishing, pp. 89-127, 2018.

[15] EN 1936, Natural stone test methods. Determination of real density and apparent density, and of total and open porosity, Brussels: CEN, 2006.

[16] EN 1925, Natural stone test methods. Determination of water absorption coefficient by capillarity, Brussels: CEN, 1999.

[17] EN 1926, Natural stone test methods. Determination of uniaxial compressive strength, Brussels: CEN, 2006.

[18] G. Wright, Ancient building in Cyprus Vol. 1, Leiden: E.J. Brill, 1992.

[19] R. Illampas, I. Ioannou and D. Charmpis, "Adobe bricks under compression: Experimental investigation and derivation of stress-strain equation," Construction and Building Materials, vol. 53, no. 1, pp. 83-90, 2014.

[20] EN 1996-1-1, Eurocode 6: Design of masonry structures - Part 1-1: General rules for reinforced and unreinforced masonry, Brussels: CEN, 2005.

[21] A. Marques, J. Morais, P. Morais, M. Veiga, C. Santos, P. Candeias and J. Ferreira, "Modulus of elasticity of mortars: Static and dynamic analyses," Construction and Building Materials, vol. 232, pp. 1-9, 2020.

[22] C. Syrmakezis and P. Asteris, "Masonry failure criterion under biaxial stress state," Journal of Materials in Civil Engineering, vol. 13, no. 1, pp. 58-64, 2001.

[23] EN 1998-1, Eurocode 8: Design of structures for earthquake resistance - Part 1: General rules, seismic actions and rules for buildings, Brussels: CEN, 2004.

[24] P. Asteris, "On the Structural Analysis and Seismic Protection of Historical Masonry Structures," The Open Construction and Building Technology Journal, vol. 2, pp. 124$133,2008$. 